\title{
MORPHOLOGICAL DESCRIPTION OF THE GASTROPOD Heleobia australis (HYDROBIIDAE) FROM EGG TO HATCHING
}

\author{
Raquel A. F. Neves ${ }^{1 *}$, Jean Louis Valentin and Gisela M. Figueiredo \\ 1Universidade Federal do Rio de Janeiro \\ Programa de Pós-Graduação em Ecologia (PPGE-UFRJ) \\ Laboratório de Zooplâncton Marinho \\ Av. Professor Rodolpho Rocco 211, Cidade Universitária, Rio de Janeiro, RJ, Brasil. \\ CEP: 24949-900 \\ *Corresponding author: raquelneves@ufrj.br
}

Hydrobiidae family (Caenogastropoda) has a global distribution in the intertidal zones of lagoons and estuaries (KABAT; HERSHLER, 1993). They constitute a diverse group of gastropods consisting of more than 1000 species (BOSS, 1971) and they play an important role in the benthic food web (KABAT; HERSHLER, 1993). In South America, Heleobia australis (Orbigny, 1835) is the dominant species of the Hydrobiidae family and it is an important food source for many species (ALBERTONI et al., 2003). Heleobia australis occurs in estuarine systems and coastal lagoons from Rio de Janeiro, Brazil to the Rio Negro, Argentina (SILVA; VEITENHEIMERMENDES, 2005), and it forms dense populations that reach up to 40,000 ind. $/ \mathrm{m}^{2}$ (BEMVENUTI et al., 1978). It is a gonochoristic species with internal fertilization and the sperm may be stored for some time before fertilization, as described for other Gastropoda (KOHN et al., 1987). As protostomes, $H$. australis has spiral and determinate cleavage. Their eggs have an animal-vegetal polarity that defines the anterior-posterior axis of the embryo (COLLIER, 1997; NIELSEN, 2004). Related species deposits their egg masses from which pelagic veligers develop (SOLA, 1996), and H. australis has been observed to present a similar development (pers. observation).

In order to better understand ecological, behavioral and taxonomic aspects of organisms it is important to know their morphological characteristics throughout their life cycle. However, studies of Hydrobiidae life cycles are still rare, particularly as regards their development from eggs to veliger larvae. For $H$. australis, despite its abundance, no stage of development has yet been described. This is thus the first study to describe the development of this species from egg to hatching by continuous observation. The characterization of this stage may help in the identification of the species. KOHN et al. (1987) suggested using pigmentation and velar lobe shape to identify living specimens.

Heleobia australis was sampled in two areas of Guanabara Bay (Rio de Janeiro, Brazil) (2284'S $043^{\circ} 20^{\prime} \mathrm{W} ; 22^{\circ} 76^{\prime} \mathrm{S} 043^{\circ} 20^{\prime} \mathrm{W}$ ) using a Van-veen grab $\left(0.05 \mathrm{~m}^{2}\right)$ in May and September, 2009. The sediment in the regions sampled was muddy (silt-clay), without any vegetation, and had a low dissolved oxygen concentration (VALENTIN et al., 1999).

Egg masses were separated from thirty adults and kept in covered 150-ml Petri dishes with filtered $(0.07 \mu \mathrm{m})$ sea water at $23^{\circ} \mathrm{C}$, the same temperature as that recorded in the natural habitat. Then the eggs were isolated and classified according to their stage and maintained under the same conditions. A few eggs in each stage were observed daily and photographed using a Canon camera attached to a Zeiss Axiostar optic microscope. The images were then analyzed and the embryos measured using the Carl Zeiss imaging solutions program Axio Vision (V 4.5).

The egg masses were observed attached to the adult shells (Fig. 1A), which is typical of the Hydrobiidae. Breeding seems to occur year-round in Guanabara Bay. As with other species of Hydrobiidae, mature females lay their fertilized eggs in capsules (or egg masses), preferably on live shells of their own species (FISH; FISH, 1974), but they may also be laid on dead shells, shells of other species, on sand grains, or algae (ANDERSON, 1971). The egg masses of $H$. autralis were yellow and consisted of capsules, each one containing one white egg that developed into a veliger larva. The number of eggs per egg mass varied between 10 and $15 \quad(n=30)$. Some eggs had not completed their development and different development stages were to be found in the same egg mass; embryos in the initial stage of development and post-hatching capsules were observed in the same egg mass. Despite not being possible to determine the timing of development of each stage, the stages were classified in accordance with the development proposed by Russo and Patti (2005).

A. Pre-division phase: egg before the cleavage. The capsules are of spherical shape and compact. The egg diameter was of about $80 \mu \mathrm{m}$ and the capsule about $120 \mu \mathrm{m}$ (Fig. 1B; $\mathrm{n}=15$ ). 
B. Cleavage: the first two cleavages and the formation of the four-cell stage took place. The cell diameter was of about $96 \mu \mathrm{m}$, and the capsule $120 \mu \mathrm{m}$ (Fig. $1 \mathrm{C} ; \mathrm{n}=1)$.

C. Formation of a blastula from a morula, an embryo filled evenly with cells. The cell diameter was about $98 \mu \mathrm{m}$ and the capsule about $120 \mu \mathrm{m}(\mathrm{n}=2)$.

D. Gastrulation: No embryo was observed at this development stage.Pre-torsional veliger: the velum has developed and the osphradium become visible. Torsion had not yet occurred, indicating the pretorsional veliger stage. The larval diameter was of about $100 \mu \mathrm{m}$ and the capsule of about $120 \mu \mathrm{m}$ (Fig. 1D; $n=4$ ).
E. Pre-torsional veliger: the velum has developed and the osphradium become visible. Torsion had not yet occurred, indicating the pre-torsional veliger stage. The larval diameter was of about $100 \mu \mathrm{m}$ and the capsule of about $120 \mu \mathrm{m}$ (Fig. 1D; $\mathrm{n}=4$ ).

F. Post-torsional veliger: torsion has taken place; veligers (of about $150 \mu \mathrm{m}$ diameter) actively swam inside the capsules and fed on internal material of the capsule through movements of the ciliated velum (Fig. 1E; $n=6$ ).

G. Hatching: a thin slit became evident in the top of the capsule. The slit gradually opened further, and, when it was sufficiently large, the veligers swam out of the capsule. The larval diameter after hatching was of about $160 \mu \mathrm{m}$ (Fig. $1 \mathrm{~F} ; \mathrm{n}=15$ ).
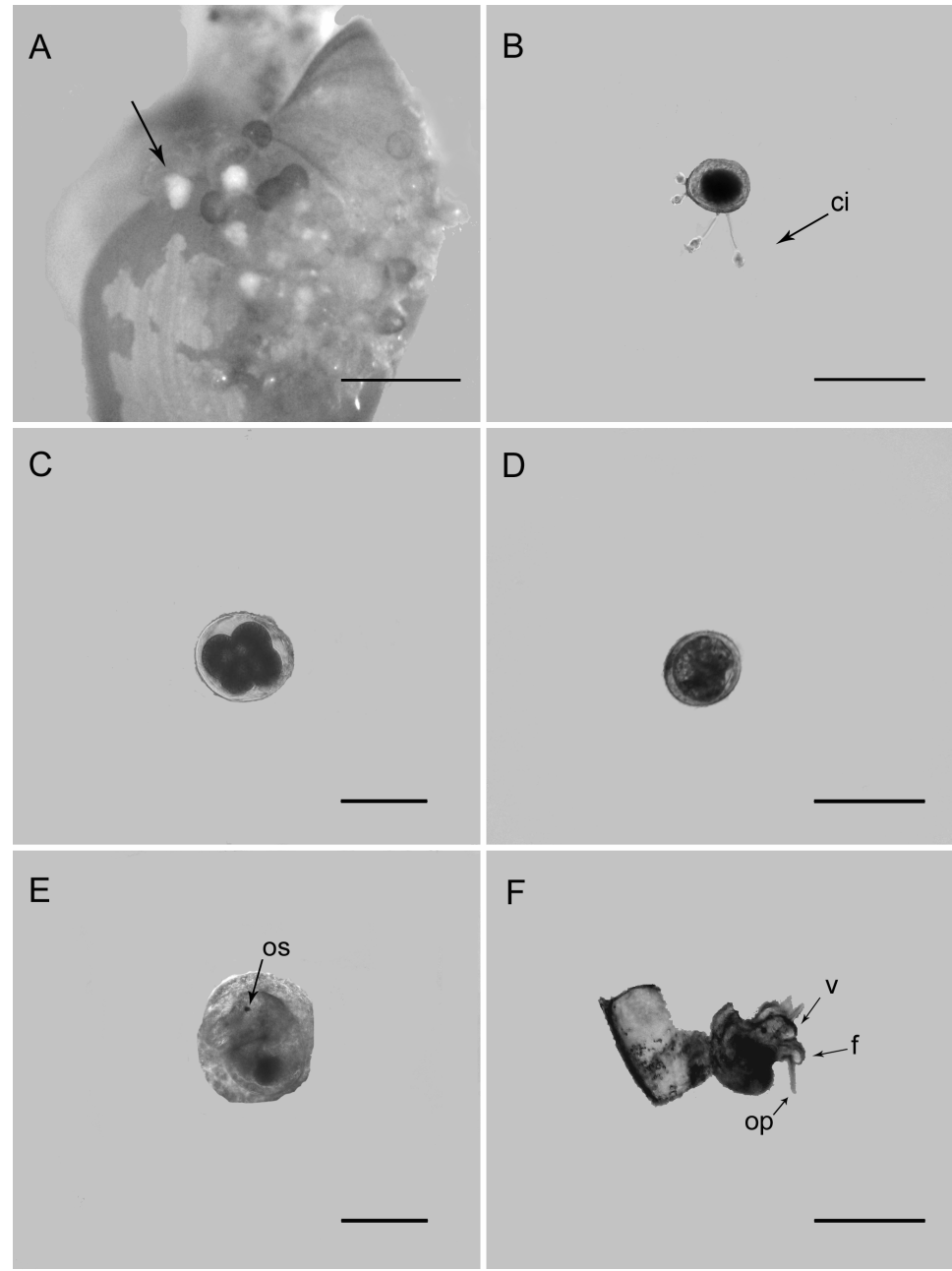

$\mathrm{F}$

Fig. 1. Development of Heleobia australis. A. Egg mass on adult shell. B. Egg before initial stage. C. Four-cell stage. D. Pre-torsional veliger. E. Post-torsional veliger. F. Hatching. Abreviations: ci, epibiont ciliates of Peritrichia subclass (protozoa); os, osphradium; v, velum; f, foot; op, operculum. Scale bars: $\mathbf{A}=0.01 \mathrm{~mm} ; \mathbf{B}=100 \mu \mathrm{m}$; $\mathbf{C}=100 \mu \mathrm{m} ; \mathbf{D}=100 \mu \mathrm{m} ; \mathbf{E}=100 \mu \mathrm{m} ; \mathbf{F}=100 \mu \mathrm{m}$. All photographs were taken at 10x magnification. 
Several ciliate protozoans live as epibionts on animals and plants, using them as substrate. The associations may not be obligatory, and the epizoic communities are generally characterized by a high number of species which may inhabit highly specialized niches (FENCHEL, 1987). Some eggs of H. australis presented epibiont ciliates of Peritrichia subclass, ciliates in this subclass provided many examples of an epizoic way of life, living on other molluscs (DIAS et al., 2006).

Veligers hatched after completing only the first phase of torsion, which indicate a mixed benthopelagic development previously shown to exist in Rissoidae species by Russo and Patti (2005). This phase involves mechanical, enzymatic or osmotic processes (SULLIVAN; BONAR, 1984). Three days after the isolation of the egg, fifteen veligers hatched (Fig. 2) from the late stages of the embryo. The operculum and foot of the veliger were already developed at hatching (Fig.1F). Internal structures and the osphradium could be seen through the transparent larval shell (protoconch; Fig. 1E). The expandable velum serves for respiration, locomotion, and feeding (KOHN et al., 1987). We observed veligers opening the operculum and expanding their velums outside the protoconch; the velum is covered with cilia which are used to capture small particles of food (Fig. 2). Velum size can be an indicator of the pelagic longevity of veliger larvae (KOHN et al., 1987). Heleobia australis has a simple bilobed velum which may indicate a short pelagic larval life considering that veligers with long pelagic larval periods have large velums and elaborated lobes.

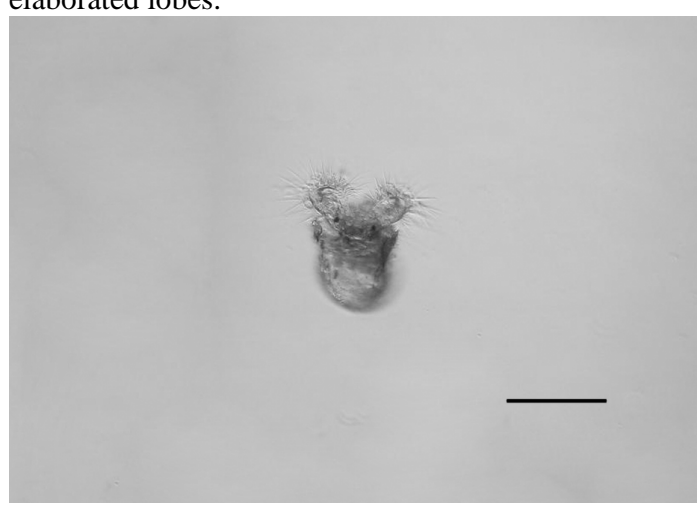

Fig. 2. Swimming veliger of Heleobia australis. Scale bar: $100 \mu \mathrm{m}$.

The world-wide distribution of the Hydrobiidae has led to the appearance of morphological, ecological, and behavioral variations among the species within this family. Some species have a developmental mode similar to that of Heleobia australis. For example, the hydrobiid from Great
Britain, Hydrobia ulvae (Pennant, 1777), produces capsules or egg masses, each capsule containing several eggs (diameter: $70-90 \mu \mathrm{m}$ ) within a mucous mass and these then develop into planktotrophic veliger larvae (SOLA, 1996); the hydrobiid from Poland, Bythinella austriaca (Frauenfeld, 1856), has an intracapsular veliger with indirect development and which has a highly reduced velum, the capsule containing a single egg or embryo (diameter: $140 \mu \mathrm{m}$ ) which can be seen through the transparent capsule wall (SZAROWSKA, 1996). Other species have a developmental mode which is clearly distinct from that of $H$. australis. For instance, the Patagonian freshwater hydrobiidae Heleobia hatcheri (Pilsbry, 1911) is an oviparous parthenogenetic species with direct development. Egg capsules contain one egg laid singly, and some snails had capsules on their shells (MARTÍN, 2002). Parthenogenesis has also been confirmed in the Australian hydrobiid Potamopyrgus antipodarum (Gray, 1843), an ovoviviparous species (HERSHLER; PONDER, 1998). Given the variety of snails' development, this study aimed to provide the description of the initial stages of a tropicalsubtropical species, $H$. australis.

This brief morphological description of intracapsular development and the larval stages of $H$. australis should provide useful information for further studies that compare the morphology of $H$. australis eggs and larvae with those of other species. Besides the morphological description of development, it is also important to assess the growth and timing of development in the early stages of gastropods and further studies must therefore be conducted. Further, ecological studies, on aspects such as feeding, settlement and predation, during the first days of this gastropod's life, are now needed.

\section{ACKNOWLEDGEMENTS}

We are grateful to Roberto Júnior Pedroso Dias for his identification of ciliates, and to Cristiano Coutinho and Emilio Lanna for their comments on the manuscript. R.A.F. Neves was financially supported by a Capes-Proex fellowship. The project was supported by FAPERJ and CNPq grants.

\section{REFERENCES}

ALBERTONI, E. F.; PALMA-SILVA, C.; ESTEVES, F. A. Natural diet of three species of shrimp in a tropical coastal lagoon. Braz. Arch. Biol. Technol., v. 46, p. 395-403, 2003.

ANDERSON, A. Intertidal activity breeding and the floating habit of Hydrobia ulvae in the Ythan Estuary. J. mar. biol. Assoc. U. K., v. 51, p. 423-437, 1971. 
BEMVENUTI, C. E.; CAPITOLI, R. R.; GIANUCA, N. M. Estudos de ecologia bentônica na região estuarial da Lagoa dos Patos II- Distribuição quantitativa do macrobentos infralitoral. Atlântica, v. 3, p. 23-32, 1978.

BOSS, K. J. Critical estimate of the number of recent Mollusca. Occ. Pap. Mollusks Mus. Comp. Zool., Harvard Univ., v. 3, n. 40, p. 81-135, 1971.

COLLIER, J. R. Gastropods, the snails. In: GILBERT, S. F.; RAUNIO, A. M. (Ed.). Embryology, constructing the organism. Massachusetts: Sinauer Associates, 1997. p. 189-217.

DIAS, R. J. P.; D’ÁVILA, S.; D’AGOSTO, M. First record of epibionts Peritrichids and Suctorians (Protozoa, Ciliophora) on Pomacea lineata (Spix, 1827). Braz. Arch. Biol. Technol., v. 49, p. 807-812, 2006.

FENCHEL, T. Ecology of Protozoa. Madison: Science Tech Publishers, 1987. 197 p.

FISH, J. D.; FISH, S. The breeding cycle and growth of Hydrobia ulvae in Dovey estuary. J. mar. biol. Assoc U. K., v. 54, p. 685-697, 1974.

HERSHLER, R.; PONDER, W. F. A review of morphological characters of Hydrobioid snails. Smithson. Contr. Zool., v. 600, p. 1-55, 1998.

KABAT, A. R.; HERSHLER, R. The prosobranch snail family Hydrobiidae (Gastropoda: Rissooidea): review of classification and supraspecific taxa. Smithson. Contrib. Zool., v. 547, p. 1-94, 1993.

KOHN, A. J.; PALMER, A. R.; SHIMEK, R. L. Phylum Mollusca, Class Gastropoda, Subclass Prosobranchia. In: STRATHMANN, M. F. (Ed.). Reproduction and development of marine invertebrates of the Northern Pacific Coast: Data and methods for the study of eggs, embryos, and larvae. Washington: University of Washington Press, 1987. p. 220- 267.

MARTÍN, P. R. Evidence for parthenogenesis and natural imposex in the Patagonian freshwater snail Heleobia hatcheri (Gastropoda: Hydrobiidae). J. molluscan Stud., v. 68 , p. $291-295,2002$.
NIELSEN, C. Trocophora larvae: cell-lineages, ciliary bands, and body regions. 1. Annelida and Mollusca. J. expl Zool. (Mol. Dev. Evol.), v. 302B, p. 35-68, 2004.

RUSSO, G. F.; PATTI, F. P. Early life history of two closely related gastropods, Rissoa auriscalpium and Rissoa italiensis (Caenogastropoda: Rissoidae). Mar. Biol., v. 47, p. 42-437, 2005

SILVA, M. C. P.; VEITENHEIMER-MENDES, I. L. Hydrobiidae (Gastropoda, Neotaenioglossa, Rissooidea) da planície costeira do Rio Grande do Sul. Ulbra Ciênc., Rev. laborat. Divulg. cient., v. 3, p. 1-13, 2005.

SOLA, J. C. Population dynamics, reproduction, growth, and secondary production of the mud-snail Hydrobia ulvae (Pennant). J. exp. mar. Biol. Ecol., v. 205, p. 49-62, 1996.

SULLIVAN, C. H.; BONAR, D. B. Biochemical characterization of the hatching process of Ilyanassa obsoleta. J. expl Zool., v. 229, p. 223- 234, 1984.

SZAROWSKA, M. The egg capsules of Bythinella austríaca (Frauenfeld, 1856) with observations on the veliger and embryonic shell. J. molluscan Stud., v. 62, p. 546-549, 1996.

VALENTIN, J. L.; TENENBAUM, D. R.; BONECKER, A. C. T.; BONECKER, S. L. C.; NOGUEIRA, C. R.; VILLAC, M. C. O sistema planctônico da Baía de Guanabara: Síntese do conhecimento. In: SILVA, S. H. G.; LAVRADO, H. P. (Ed.). Ecologia dos ambientes costeiros do estado do Rio de Janeiro. Rio de Janeiro: Oecologia Brasilensis (PPGE-UFRJ), 1999. p. 35-59.

(Manuscript received 26 January 2010; revised 25 March 2010; accepted 14 April 2010) 